九州大学学術情報リポジトリ

Kyushu University Institutional Repository

\title{
The Combustion of a Diesel Oil-Based/Coal/Water Slurry in a Horizontal Cylindrical Furnace: An Experimental Investigation
}

Motaz Mabrouk Salama

Interdisciplinary Graduate School of Engineering Sciences, Kyushu University

Elsihy, Elsaeed

Mechanical Power Engineering Department, Faculty of engineering, Helwan University

Mone ib, Hany

Mechanical Power Engineering Department, Faculty of engineering, Helwan University

Kamal, Mohamed

Central Metallurgical Research and Development Institute

他

https://doi.org/10.5109/4738568

出版情報: Proceedings of International Exchange and Innovation Conference on Engineering \& Sciences (IEICES). 7, pp.64-70，2021-10-21. 九州大学大学院総合理工学府

バージョン:

権利関係 : 


\title{
The Combustion of a Diesel Oil-Based/Coal/Water Slurry in a Horizontal Cylindrical Furnace: An Experimental Investigation
}

\author{
Motaz Mabrouk Salama ${ }^{1,2^{*}}$, Elsaeed Elsihy ${ }^{2}$, Hany Moneib ${ }^{2}$, Mohamed Kamal $^{3}$, Mahmoud Shahein ${ }^{2}$ \\ ${ }^{1}$ Interdisciplinary Graduate School of Engineering Sciences (IGSES), Kyushu University, Fukuoka, Japan. ${ }^{2}$ Mechanical \\ Power Engineering Department, Faculty of engineering, Helwan University, Cairo, Egypt. \\ ${ }^{3}$ Central Metallurgical Research and Development Institute, El -Tabbin, Cairo, Egypt. \\ *Corresponding author: motaz.salama.203@s.kyushu-u.ac.jp or motazmabrouk145@gmail.com
}

\begin{abstract}
The current work investigates the use of a coal/oil/water slurry as an alternative fuel in boilers and industrial furnaces. Experiments were carried out on chosen flames with constant input heat throughput and variable air/fuel ratios for three major oil/coal/water mixtures (on a mass basis) as follows: (Case1: pure oil; reference case), (Case2: 80\%, $10 \%$, $10 \%$ ) and (Case $3: 70 \%, 15 \%, 15 \%)$. The results showed that case 2 had a significant improvement in both heat transfer to the cooling jacket and combustion efficiency, which was accompanied by a decrease in NOx emissions. Further increase in the ratio of coal and water in the fuel mixture (case 3) produced a significant degradation in the overall combustion characteristics, referring to an upper limit of coal and water loading ratios of only 10\%. Oil-coal-water slurries are considered a significant alternative source of energy.
\end{abstract}

Keywords: coal; oil/coal/water slurry; coal slurries; combustion characteristics.

\section{INTRODUCTION}

The ever-increasing demands for energy which is coupled with stringent environmental regulations have made research in this field a top priority worldwide. This situation has enforced scientists and researchers to introduce, develop alternative renewable energy as well as to implement the reuse of low-grade fossil fuel (mainly coal; plentiful reserves) in parallel with the depleted oil and gas reserves while maintaining the conceptual policies of cost-effective clean energy [1]. In utility and commercial boilers, coal-slurry fuels have arisen as suitable technological alternatives to oil and gaseous fuels. Despite current low prices and plentiful oil, crude oil market trends are nonstationary and nonlinear [2]. Many studies have concluded that coal burning is a significant cause of air pollutants $[3,4]$, which have direct and indirect effects on humans. As a result, long-term oil availability concerns, economic considerations, and environmental impacts make coal-slurry technology appealing and beneficial. Coal-oil slurry (COS) and coalwater slurry (CWS) have piqued the interest of many researchers during the last two decades since they are coal-based liquid fuels that can be fed into pipes to replace oil fuels and as a result, used as boiler fuels. The combustion process is vital in the different industrial processes and applications such as electrical power generation, automotive, thermal furnaces, and commercial boilers. As a result, it is very important to investigate the various influences that greatly affect the combustion characteristics of such fuels, and the establishment of environmental and economic indicators of burning them in laboratory experiments. Many studies have undertaken the different issues related to coal slurries. The previous work introduced in this field is collected as possible and listed in this section.

Combustion Performance and atomization of a COS (diesel fuel and olive-cake slurry) were studied by $\mathrm{M}$. Abu-Qudais and G. Okasha [5]. The results showed that a loading ratio of $7 \mathrm{wt} . \%$ of olive-cake (OC) in the diesel fuel resulted in increasing the flame temperature, hence the heat transfer and the combustion efficiency in comparison to the combustion of pure diesel oil. A novel process for the preparation of an ultra-clean superfine coal-oil slurry was presented by [6]. The process included a high-pressure water-jet mill and a pumping slurry jet mill for coal superfine comminution. The mean diameter of coal particles in the slurry was $2.71 \mu \mathrm{m}$. It was concluded that the ultra-clean superfine coal-oil slurry has a heat value and level of stability are greater than those of carbinol, ethanol and dimethyl ether, in addition to lower viscosity. The effects of volume concentration, particle size and slurry temperature on wall slip behavior (wall slip velocity, critical wall shear stress and slippage contribution) were investigated by [7] The influence of sewage sludge and chemical additives on the stability of coal-water slurry was investigated by [8]. The maximum solids loading, stability and rheological properties of coal-sludge slurries were investigated and compared with those of coal-water slurries. Experiments on the production of suspension fuel from fuel oil and charcoals were conducted in [9]. The rheological characteristics of dispersions and suspension fuel condition indices were tested, taking into consideration the influences of concentration, moisture content, ash content, particle size, apparent density, and the solid phase preparation process. The combustion of the mixture of filter cake of non-baking coal and waste oils in different states namely slurry, gel, and solid states was experimentally investigated [10]. A comparative analysis of the different mixtures was produced in terms of ignition delay times, minimum ignition temperatures, the heat of combustion, anthropogenic emissions concentration, and the relative efficiency of fuels. The combustion characteristics of sub-bituminous, ultrafine coal particles-light diesel oil mixtures were investigated inside a horizontal, water-cooled cylindrical furnace, with a coaxially fitted burner provided with an airassisted nozzle essential for the different-blended mixtures atomization [11]. To decrease the environmental impact of the burning of oils and coal-oil slurries, the coal-water slurry is considered a promising fuel to mitigate hazardous emissions such as nitrogen oxides and sulfur oxides. Kleczkowska, A. K. [12] investigated the combustion of the coal-water 
suspension in air and in the fluidized beds. NOx emissions concentration and the effect of particle size on the suspension stability were studied. It was concluded that less amounts of NOx emissions were released, and the use of various particle sizes contributed to agglomeration. And in the light of development and progress achieved in visual photography methods, the flame characteristics and in-situ atomization of CWS were studied using a developed imaging technique [13]. The instantaneous flame, time-averaged flame, and flame oscillation were addressed. The droplet size distribution, rate of change of the droplet concentration, and timedependent droplet size were obtained using the statistical approach to assess the atomization process's efficiency and stability. Another study was applied to analyze the atomization and breakup of around coal-water slurry jet by an annular air jet by using a high-speed digital camera [14]. The influence of the geometrical properties of the nozzle on the atomization performance of a CWS was examined [15]. Because of the high concentration of coal dust in the coal-water slurries, the high viscosity of the CWS fuel is considered a major problem that has a negative impact on the suspension supply into the combustion chamber and the combustion quality. This problem could be overcome by using proper additives or dispersants such as surfactants [1] to decrease the suspension viscosity $[16,17,18]$.

However, both COS and CWS have drawbacks. For instance, COS has a high viscosity which reduces the amount of oil saved, whereas CWS has a low combustion value [18]. In order to increase the combustion value of coal slurry and to reduce the viscosity, COWS (coal, oil and water slurry) was investigated [19]. Several investigators carried out their investigations on preparation and rheological properties of COWSF. $\mathrm{H}$. Zhu, et al. [19] investigated the effect of using petroleum sulfonate as dispersants on the preparation and rheological properties of Triplex synfuel containing light oil, water, and coal with various component content. It was observed that the slurry was stable and homogeneous under the effect of the different surfactants used in this experiment. Using a nonionic surfactant (Tween 80) as an emulsifying agent, H. L. Qi et al. [20] introduced a novel method of preparing coal-oil-water triplex synfuel containing gasoline, water, and coal. They examined the effect of surfactants and temperature on rheological properties as well as the ratios of the components in the slurry. It was confirmed that the best COWSF prescription was when the weight ratio of the components was $\mathrm{C}: \mathrm{W}: \mathrm{O}=45 \%, 30 \%$, and $25 \%$, respectively. As the addition amount of Tween 80 was 2.0 percent, the viscosity of COWS decreased dramatically with increasing the temperature (decreased with an improved shear rate in the range of $\left.10 \mathrm{~s}^{-1}-100 \mathrm{~s}^{-1}\right)$, and stable triplex mixture systems were prepared. The effect of coal particle size on the rheological and preparation of COWS was studied in [21] and [22]. It was reported that as the average particle size of coal decreased, the viscosity increased, resulting in an increase in irregularity and non-free flow behavior, and as a result, fluidity decreased. In terms of the cost of the fuel elements, gas species concentrations, and energy performance, a comparison of coal dust and coal slurry combustion with and without petrochemicals was presented [23]. The coal-water slurries with petrochemicals had higher indicators than the other fuels. Moreover, Galina et al. [23] investigated the effect of using special additives in the COW slurry. The study explored that sawdust, wood, charcoal, shale, and glycerol are the most attractive COWS additives. They boosted the rheological properties of COWS, furthermore, improved the environmental, economic, and energy performance. Another experiment was carried out on a coal-based, water and oil slurry to see how the rheological properties changed when flammable liquid additives were added (e.g., waste motor, turbine oils, oilwater emulsion, grease-oil mixture) [24]. Moreover, the influences of those changes on the ignition delay time of combustion, Calorific value of fuel and heat of combustion were tested.

From the literature, the majority of research is focused on rheological properties, the effect of chemical additives, temperature, coal particle size, and the percentage of the components in the coal-oil-water slurry (COWS) fuel. Furthermore, rare studies have undertaken the combustion characteristics of COWS fuel. The switching from conventional burning of Egyptian coal (EC) to oilbased, coal, and water slurries has not been investigated. The main objective of the present work is to extend our work in [11] and investigate the combustion characteristics of an oil-based, coal, and water slurry containing light diesel oil (grade 2), distilled water, and Egyptian coal (EC) without using chemical additives. Under constant input heat conditions and variable air/fuel ratios, experiments were conducted on two different combustion modes (Diesel oil flame, COWS flame) and three- different flames of various blends (Oil/Coal/Water). Also, to determine and emphasize the fuel components' ratios in the slurry for higher energy performance and environmental indicators.

\section{MATERIALS}

The coal used in the present work has been provided from El Maghara mine coal in Gabal El Maghara region in Sinai by the Egyptian General Mineral Resources Authority (EGMSA), Cairo, Egypt. According to the ASTM standard based on the fixed carbon and calorific value-based on the dry mineral matter-free basis, this coal sample was classified as sub-bituminous-B [25]. we prepared the experimental coal stock in the Central Metallurgical Research and Development Institute (CMRDI). The coal sample has been primarily crushed and sieved in standard sieves. After that, a pulverization process was carried out in a ball mill (dry grinding) to prepare the stock, resulting in ultra-fine coal powder of size $<30 \mu \mathrm{m}$. For suspension preparations, diesel oil grade 2 was adopted. The proximate analysis of ElMaghara coal and diesel oil grade 2 is presented in Table 1[25]. The water component of the COW slurry was the distilled water of specific gravity 0.996 at $30^{\circ} \mathrm{C}$.

The combustor, burner, air supply system, coal-oil-water fuel (COWF) supply system, combustor cooling water supply system, and measuring probes make up the majority of the test rig. All systems are outfitted with the requisite flow rate control equipment. In the following 
section, the test rig and various instrumentations are listed in detail. The general configuration of the experiment test rig is presented in Figure 1.

Table 1 The proximate analysis of Egyptian subbituminous coal and diesel oil grade 2 [25].

\begin{tabular}{|ll|ll|}
\hline \multicolumn{2}{|c|}{ Coal proximate analysis } & \multicolumn{2}{c|}{$\begin{array}{c}\text { Diesel oil proximate } \\
\text { analysis }\end{array}$} \\
\hline Moisture & $2.12 \%$ & Carbon & $85.5 \%$ \\
Ash & $8.26 \%$ & Hydrogen & $13.2 \%$ \\
Volatile & $51.39 \%$ & Sulfur & $0.1 \%$ \\
$\begin{array}{l}\text { matter } \\
\begin{array}{l}\text { Fixed } \\
\text { carbon }\end{array}\end{array}$ & $38.6 \%$ & Oxygen & $0.2 \%$ \\
Total sulfur & $2.9 \%$ & Calorific & 42 \\
Calorific & $6900-$ & value & $\mathrm{MJ} / \mathrm{kg}$ \\
value & 72022 & & \\
& $\mathrm{kcal} / \mathrm{kg}$ & & \\
\hline
\end{tabular}

A typical type $\mathrm{K}$ thermocouple is used to measure the inlet and outlet temperatures of water flowing into and out of the cooling water-jacket. A radially oriented inspection hole is built in the center of each segment to allow the insertion of the various measuring probes.

The burner facility was specifically designed and constructed for the firing of coal slurries (COS and COWS). The burner configuration details are illustrated in Figure 2. The burner is constructed of a thread Tconnection of $0.3 \mathrm{~m}$ length with $0.105 \mathrm{~m}$ inside diameter and a cylindrical housing of $0.35 \mathrm{~m}$ length and $0.105 \mathrm{~m}$ outside diameter. The secondary combustion air swirler of $0.09 \mathrm{~m}$ diameter with a $30^{\circ}$ vane angle was centrally positioned in the burner mouth. The swirler has 10 vanes made from a steel sheet of $0.0015 \mathrm{~m}$ thickness. As shown in Figure 3, a low-pressure, air- assisted externally atomizing nozzle is connected to the fuel nozzle holder and inserted at the center of the secondary air swirler. The combustion air was fed to the burner by a high-pressure air storage system and the atomizing airstream was fed to flow through the atomizing air holes encircling the atomizing nozzle [26].

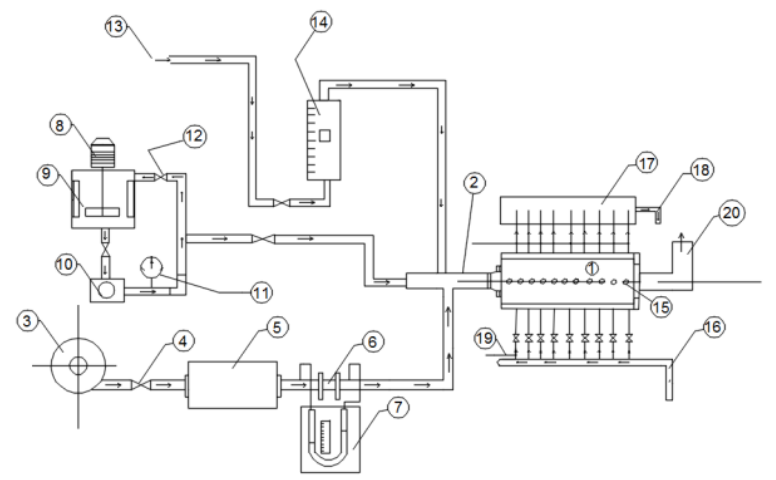

1-The combustor, 2- ECOWF burner, 3-Air blower, 4- Gate valve, 5-Air settling chamber, 6- standard orifice plate, 7- U-tube manometer, 8- Mechanical stirrer, 9-Slurry fuel tank, 10- Slurry fuel gear pump, 11- pressure gauge, 12-By-pass control valve, 13 Atomizing air-line, 14- Air flow meter, 15- Measuring tappings, 16City water header, 17- Outlet water tank, 18- hot water shower, 19. probe cooling water header, 20 - The chimney.

Figure 1 A schematic diagram of the experimental set up.

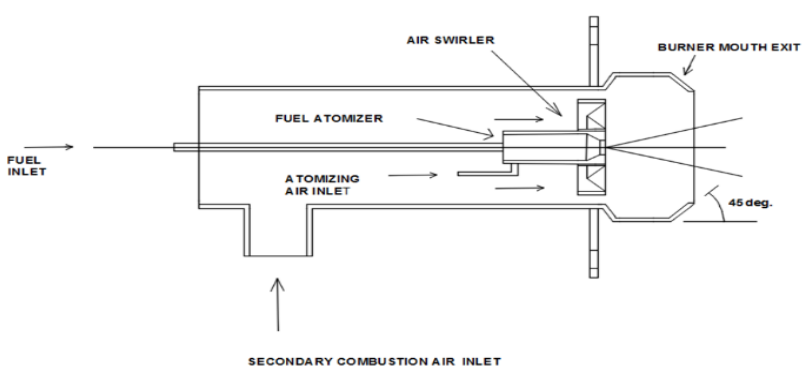

Figure 2 A schematic diagram of the burner facility.

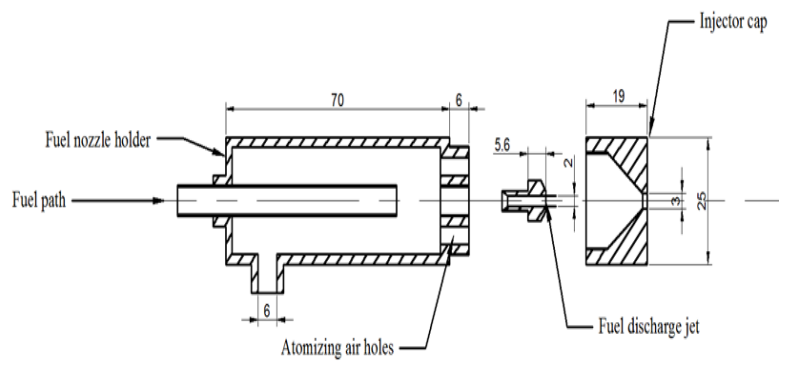

Figure 3 A schematic diagram of the fuel atomizer.

The combustion air (secondary air) is delivered to the burner by an electric blower of $7 \mathrm{HP}$. A rectangular reservoir with a $0.5 \mathrm{~m} \times 0.5 \mathrm{~m}$ cross-section and a length of $1 \mathrm{~m}$ is manufactured of $0.025 \mathrm{~m}$ thick steel sheet and connected to the blower outlet by a rectangular flange. This reservoir is used as a settling chamber to reduce pressure fluctuations caused by the air blower, maintaining a consistent flow rate across the blower's operating range. The reservoir's exit is a circular outlet tube with a diameter of $0.105 \mathrm{~m}$. A flexible hose connects this tube to the air supply line. This tube is connected to the air supply line by a flexible hose. A standard orifice plate is used to determine the airflow rate. A U-tube water manometer is used to measure the pressure difference across it. The atomizing air (Primary air) is delivered to the burner by a compressor of $4 \mathrm{HP}$ with a flexible hose of $0.008 \mathrm{~m}$. the atomizing air flow rate is measured by a calibrated airflow meter (Rotameter). The atomizing air pressure is controlled by a pressure regulator.

\section{MEASURING TECHNIQUES}

During the experimental program of the present study. The flame temperature measurements were carried out by using a type $\mathrm{S}$ thermocouple which is made of $90 \%$ platinum and $10 \%$ rhodium-platinum wires. The heat transfer to the combustor walls was calculated by measuring the flowrate of the cooling water of each segment and the difference between the water outlet and inlet temperatures. The inlet and outlet temperatures are measured by a K-type thermocouple (Nickel ChromiumCopper Nickel) located at the segment exit. To prevent the effects of air leakage on the measurement data, the inspection port is plugged during this series of tests [27]. Depending on the readings of the cooling water temperatures at the outlet and inlet and the flow rates at each segment, the heat flux gained by the combustor walls can be determined by the following formula:

$$
\mathrm{HF}=\frac{\mathrm{M} * \mathrm{C}_{\mathrm{p}} *\left(\mathrm{~T}_{\mathrm{o}}-\mathrm{T}_{\mathrm{i}}\right)}{\pi * \mathrm{D}_{\mathrm{i}} * \mathrm{~L}_{\mathrm{i}}} \quad \text { Eqn.1 }
$$


Where HF is the heat flux $\left(\mathrm{Kw} / \mathrm{m}^{2}\right), \mathrm{M}$ is the cooling water mass flow rate $(\mathrm{kg} / \mathrm{s}), \mathrm{Cp}$ is the water specific heat $(\mathrm{kJ} / \mathrm{kg} . \mathrm{K}), \mathrm{T}_{\mathrm{o}}$ is the outlet cooling water temperature, $\mathrm{T}_{\mathrm{i}}$ is the inlet cooling water temperature $\left({ }^{\circ} \mathrm{C}\right), \mathrm{D}_{\mathrm{i}}$ is the inner diameter of the combustor and $\mathrm{L}_{\mathrm{i}}$ is the segment length where $\mathrm{i}$ indicates the numbering of each segments (e.g. $i=1,2, \ldots 9)$. Axial concentrations of combustion products were measured by means of the ENERAC MODEL 2000 gas analyzer through a sample probe used to withdraw the gas sample.

\section{RESULTS AND DISCUSSION}

This current experiment aims to investigate and compare the flame structure and the combustion characteristics under two different forms of firing. These two modes of firing are:

\section{Liquid fuel (Diesel oil alone) firing. \\ 2. Multiphase fuel (COWSF) firing.}

The experimental procedures were carried out within three test runs. The first run represents the first mode of firing using diesel oil alone. While the second and the third runs represent the second type of firing using the COWS fuel with different loading ratios of coal powder and water in the diesel oil. An input heat of $266.7 \mathrm{KW}$ was constant throughout all experiments. In keeping with the blower capacity limitation, different three air: fuel ratios are optimized. Accordingly, three test runs have been carried out to find sufficient data for the required investigation. A summary of the operating conditions of the different runs considered in this study is provided in Table 2.

Table 2 The experimental program conditions.

\begin{tabular}{|c|c|c|c|c|c|c|}
\hline 茛 & 总 & $\underset{\text { 点 }}{\stackrel{8}{\sigma}}$ & 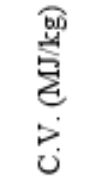 & 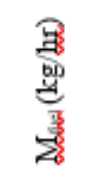 & 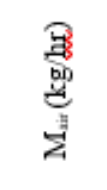 & 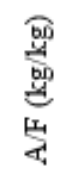 \\
\hline 1 & $\begin{array}{l}\text { Pure } \\
\text { Diesel oil }\end{array}$ & 266.7 & 42 & 22.86 & 468.63 & 20.5 \\
\hline 2 & $\begin{array}{c}\text { ECOWS } \\
(80: 10: 10)\end{array}$ & 266.7 & 36.55 & 26.28 & 517.7 & 19.7 \\
\hline 3 & $\begin{array}{l}\text { ECOWS } \\
(70: 15: 15)\end{array}$ & 266.7 & 33.82 & 28.39 & 462.75 & 16.3 \\
\hline
\end{tabular}

Figure 4 shows the axial distribution of flame temperature along the axis of the combustor for different percentages of EC and water in the diesel oil. Flame temperatures were measured by a type $S$ (Platinum/rhodium) traverse thermocouple probe. For run 1(pure diesel oil), the measurements showed that the maximum temperature of the flame was $1014.6{ }^{\circ} \mathrm{C}$. It occurred at the end of the second segment at an axial distance $X=25 \mathrm{~cm}(X / D=0.625)$ at which the mixing of air and fuel was nearly completed at the stoichiometric air: fuel ratio. As can be seen, when the EC and water were added to the diesel oil (Run 2: 10\%, 10\%), the maximum flame temperature was $1015.3^{\circ} \mathrm{C}$. Another notable change was that the peak temperature shifted towards the third segment at axial distance $X=35 \mathrm{~cm}$ $(X / D=0.875)$. This change was attributed to the faster mixing of pure diesel oil and air, which resulted in a faster chemical reaction and burning rate compared with the ECOWS fuel. While increasing the loading of the EC and water in the slurry further (Run 3: 15\%, 15\%) resulted in a reduction of the maximum flame temperature. It was $933.9^{\circ} \mathrm{C}$ and occurred at the end of the second segment at an axial distance of $25 \mathrm{~cm}(\mathrm{X} / \mathrm{D}=$ 0.625). This decrease in temperature was due to increasing the ratio of water in the slurry, which is considered an incombustible matter of zero calorific value. Moreover, the water vapor produced restrained the chemical reaction rate and increased the combustion time. For more explanation, after the axial distance $X=35 \mathrm{~cm}$ $(\mathrm{r} / \mathrm{R}=0.875)$, the trajectory of the axial temperature profile became higher than that of diesel oil in run (1). This was most likely due to the momentum of the coal particles and it is not easy to burn the coal particles like the liquid fuel. As a result, a lower burning rate and longer combustion time were exhibited. Moreover, a combined heat transfer by radiation and convection was exhibited in the downstream segments, resulting in a higher axial temperature profile at these regions than that of the diesel oil. The firing of ECOWS in run (3) continued to show the lowest trajectory of axial temperature profiles for the reasons mentioned above.

Extended measurements of temperature in terms of the radial flame temperature have been undertaken. Figure 5 illustrates the radial temperature profiles of the three flames at an axial distance $X=25 \mathrm{~cm}(X / D=0.625)$. The same trend of variation of the radial profiles was attained along the flame diameter in the three runs. Run 2 exhibited larger flame diameter, so wider volume of central recirculation zone as shown in the figure within $0.5 \leq \mathrm{r} / \mathrm{R} \leq 0.8$ than these of the reference case (run 1) and run 3 , hence higher chemical reaction zone; in which better mixing between primary jet of the atomizer and the secondary air stream was obtained.

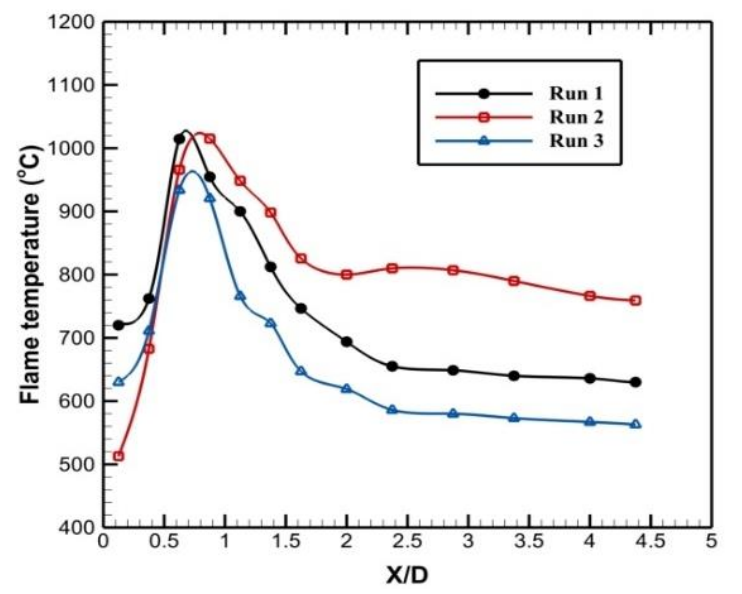

Figure 4 Axial distribution of flame temperature for different Percentages of EC and water in diesel oil.

$\mathrm{CO} 2$ and $\mathrm{O} 2$ concentrations vary around the combustor axis, as seen in Figure 6. In general, the results showed the same trend of $\mathrm{CO} 2$ and $\mathrm{O} 2$ levels at the different axial locations of the different firing modes. As seen in the figure, $\mathrm{CO} 2$ levels were greatest in the upstream area of the flames in any of the tests. The highest chemical reaction zone was reached at the second segment, indicating that this regime promoted better mixing and contact between the fuel jet and air streams. 


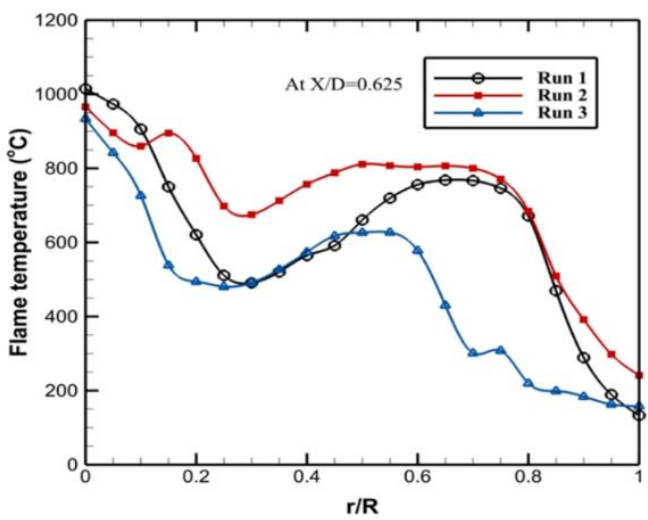

Figure 5 Radial profiles of flame temperature at an axial location $\mathrm{X} / \mathrm{D}=0.625$ of run 1,2 and 3 .

Since the outer chemical reaction zones are less intense, the local measures of $\mathrm{CO} 2$ have decreased at the downstream sections. The amount of $\mathrm{CO} 2$ produced is related to the combustion temperature and the amount of $\mathrm{O} 2$ present in the combustion chamber and this explains the contrary behavior of oxygen curve[28]. The concentration of $\mathrm{O} 2$ steadily decreased until it was absorbed almost entirely at the upstream regimes. The fuel stream consumed most of the oxygen in this area (central of the recirculation zone) in order to burn completely. Furthermore, it achieved higher concentrations in downstream sections and observed peak values at the end of the combustor, where there was less mixing between combustion air and unburned fuel particles and less reversed mass quantities. Because of the reduced rate of reaction due to the greater mass of water, the $\mathrm{O} 2$ concentration in run 3 was higher than those in runs 1 and 2. Finally, burning of COW slurry takes the advantage of lower release of carbon dioxide to the atmosphere and becomes significantly lower by increasing the coal and water components in the mixture.

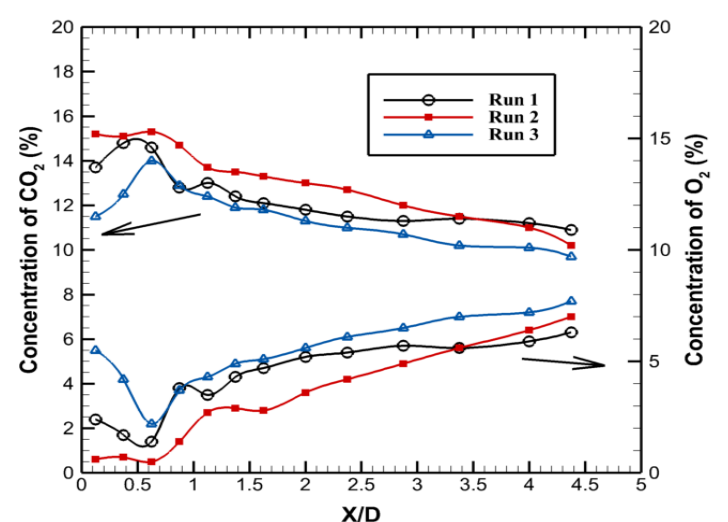

Figure 6 Axial Concentration of carbon dioxide and oxygen.

Figure 7 shows the axial variation of NOx (nitrogen oxides) concentration along the combustor. An interesting and comparative analysis of NOx emissions is introduced. Three different patterns of reaction can release NOx. Thermal NOx is produced when airborne nitrogen reacts with oxygen radicals at temperatures exceeding $1300^{\circ} \mathrm{C}$ and increases with temperature. At temperatures above $1300^{\circ} \mathrm{C}$ and low oxygen concentrations in the existence of hydrocarbons, prompt NOx is produced from airborne $\mathrm{N}$. Thermal and prompt
NOx formation are of minor significance in our study conditions due to relatively low furnace temperatures. If the nitrogen content of the fuel increases, so do the NOx emissions. The oxidation of the fuel nitrogen content through a series of chemical reactions is considered the dominant source of NOx emissions[29]. In the case of the diesel oil firing mode; by the aid of figure 4 and figure 6 ; a relatively high temperature of $1014.6^{\circ} \mathrm{C}$ at the second section at $X=25 \mathrm{~cm}(X / D=0.625)$ and the availability of oxygen resulted in a maximum axial concentration of 91 ppm of NOx. It was observed that NOx emissions decreased at the coming downstream sections due to lower levels of temperature. For COWS fuel, compared to NOx emissions from the combustion of pure diesel oil fuel, the curves showed a common feature; Nitrogen oxides were formed from the fuel nitrogen (the volatile nitrogen released from the coal). Even though the maximum temperatures in runs 1 and 2 are almost identical, the figure reveals that NOx formation is higher in case 2 than the reference case (run 1) with $141 \mathrm{ppm}$ concentration, where the maximum temperatures existed at $0.625 \leq \mathrm{X} / \mathrm{D} \leq 0.875)$. NOx levels were observed to be lower in run 3 ( $15 \%$ coal, $15 \%$ water) and recorded zerovalue at some locations. The curve of run 3 was optimized to show the most likely trend of NOx concentration. Given that water is a main component of coal-oil-water slurry fuel, its existence has a significant impact on NOx concentration. The combustion zone temperature and chemical reaction rate are further reduced as the water content increases and diesel oil loading decreases, which reduces the release of NOx emissions [30,31]. This indicates that increasing blending proportions of coal powder and water could be beneficial with regard to the release of NOx.

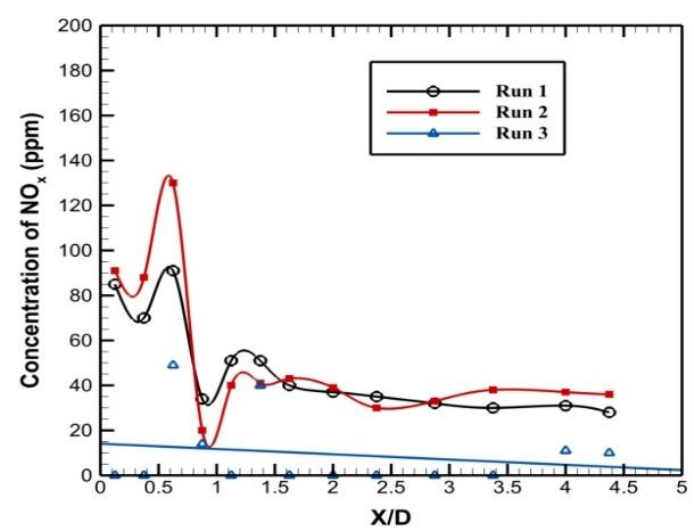

Figure 7 Axial concentration of Nitrogen oxides.

Figure 8 shows the effect of varying percentages of coal particles and water in diesel oil on the axial distribution of heat flux intensity along the combustor walls. As a common feature, all curves exhibit the same trend. It was noticed that the peak value of the heat flux occurs near the burner end occasionally at $\mathrm{X} / \mathrm{D}=1.2$, due to the intense combustion zone at this region.

It is well known that the radiative properties of solid flames are better than that of oil flames because of the emissivity difference. The higher emissivity of solid 
flame is due to soot formation and the high luminosity of ash particles present in solid fuel. It was noticed that the distribution of heat flux to the cooling water in case of run (2) is higher with respect to run (1) and run (3). while further increasing the loading of coal and water to $15 \%$

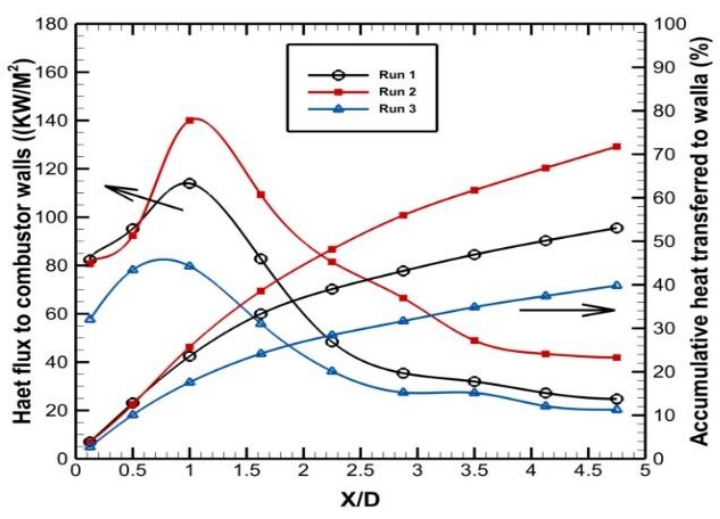

Figure 8 Heat flux and accumulative heat distributions to the water jacket along the combustor axis.

(run 3), the peak value of the heat flux is shifted before that of the case of firing pure diesel (run 1) at $\mathrm{X} / \mathrm{D}=0.8$. At this heat supply, applying EC and water with percentages of $10 \%$ by weight to the diesel oil fuel is seen to significantly lead to raising the combustion intensity and helps to increase the heat released, resulting in higher heat flux to the wall axially along the combustor than the diesel oil flame. The accumulative heat is an important parameter which indicates to combustion efficiency [34]. Correspondingly, higher heat flux and accumulative heat of ECOWS (10\% coal, $10 \%$ water) was higher than that produced from burning only diesel oil and ECOWS (15\% coal, $15 \%$ water).

\section{CONCLUSIONS}

In the current work, it was concluded that Increasing coal and water loadings by up to $10 \%$ improves the combustion process in terms of heat flux and combustion byproducts and accumulative heat to the cooling water while slight decrease in the peak temperature. However, further increasing of the ratios of coal and water in the slurry up to $15 \%$ wt reduces the rate of heat transfer and the peak temperature accompanied with a significant degradation in the overall combustion characteristics, referring to an upper limit of coal and water loading ratios of only $10 \%$.

According to the data analysis, ECOWS could be considered a potential alternative in Egypt in the near future.

\section{REFERENCES}

[1] D. M. Guldi, Alternative fuel technologies, vol. 9, no. 12. 2007.

[2] P. Feng, X. Li, J. Wang, J. Li, H. Wang, and L. He, "The mixtures of bio-oil derived from different biomass and coal/char as biofuels: Combustion characteristics," Energy, vol. 224, 2021, doi: 10.1016/j.energy.2021.120132.
[3] S. Song, Y. Wang, Y. Wang, T. Wang, and H. Tan, "The characteristics of particulate matter and optical properties of Brown carbon in air lean condition related to residential coal combustion," Powder Technol., vol. 379, pp. 505-514, 2021, doi: 10.1016/j.powtec.2020.10.082.

[4] X. Wang et al., "Characterization of organic aerosol produced during pulverized coal combustion in a drop tube furnace," Atmos. Chem. Phys., vol. 13, no. 21, pp. 10919-10932, 2013, doi: 10.518

4/acp-13-10919-2013.

[5] M. Abu-Qudais and G. Okasha, "Diesel fuel and olive-cake slurry: Atomization and combustion performance," Appl. Energy, vol. 54, no. 4, pp. 315-326, 1996, doi: 10.1016/0306-2619(95)00077-1.

[6] L. Cui, L. An, and H. Jiang, "A novel process for preparation of an ultra-clean superfine coal-oil slurry," Fuel, vol. 87, no. 10-11, pp. 2296-2303, 2008, doi: 10.1016/j.fuel.2007.10.017.

[7] L. Chen, Y. Duan, M. Liu, and C. Zhao, "Slip flow of coal water slurries in pipelines," Fuel, vol. 89, no. 5, pp. 1119-1126, 2010, doi: 10.1016/j.fuel.2009.09.016.

[8] W. Li, W. Li, H. Liu, and Z. Yu, "Influence of sewage sludge on the slurryability of coal-water slurry," Fuel, vol 88, no. 11, pp. 2241-2246, 2009, doi: 10.1016/j.fuel.2009.05.002.

[9] I. I. Lishtvan, P. L. Falyushin, E. A. Smolyachkova, and S. I. Kovrik, "Fuel suspensions based on fuel oil, peat, waste wood, and charcoal," Solid Fuel Chem., vol. 43, no. 1, pp. 1-4, 2009, doi: 10.3103/S0361521909010017. [10] K. Vershinina, G. Nyashina, V. Dorokhov, and N. Shlegel, "The prospects of burning coal and oil processing waste in slurry, gel, and solid state," Appl. Therm. Eng., vol. 156, no. April, pp. 51-62, 2019, doi: 10.1016/j.applthermaleng.2019.04.035.

[11] Els. S. ELSihy, M. M. Salama, M. A. Shahein, H. A. Moneib, and M. K. Abd EL-Rahman, "Combustion Characteristics of Ultrafine Coal Particles-Light Diesel Oil Mixtures in a Cylindrical Horizontal Furnace," J. Energy Resour. Technol., vol. 143, no. 7, pp. 1-11, 2021, doi: 10.1115/1.4048711.

[12] A. Kijo-Kleczkowska, "Combustion of coal-water suspensions,” Fuel, vol. 90, no. 2, pp. 865-877, 2011, doi: 10.1016/j.fuel.2010.10.034.

[13] Z. Xue, Q. Guo, Y. Gong, Y. Wang, and G. Yu, "Insitu atomization and flame characteristics of coal water slurry in an impinging entrained-flow gasifier," Chem. Eng. Sci., vol. 190, pp. 248-259, 2018, doi: 10.1016/j.ces.2018.06.039.

[14] H. Zhao, H. F. Liu, J. L. Xu, W. F. Li, and W. Cheng, "Breakup and atomization of a round coal water slurry jet by an annular air jet," Chem. Eng. Sci., vol. 78, pp. 6374, 2012, doi: 10.1016/j.ces.2012.05.007.

[15] S. G. Daviault, O. B. Ramadan, E. A. Matida, P. M. Hughes, and R. Hughes, "Atomization performance of petroleum coke and coal water slurries from a twin fluid atomizer," Fuel, vol. 98, pp. 183-193, 2012, doi: 10.1016/j.fuel.2012.02.042.

[16] D. Das, U. Dash, J. Meher, and P. K. Misra, "Improving stability of concentrated coal-water slurry using mixture of a natural and synthetic surfactants," Fuel Process. Technol., vol. 113, pp. 41-51, 2013, doi: 10.1016/j.fuproc.2013.02.021.

[17] Y. J. Shin and Y. H. Shen, "Preparation of coal slurry with organic solvents," Chemosphere, vol. 68, no. 
2, pp. 389-393, 2007, doi: 10.1016/j.chemosphere.2006.12.049.

[18] I. Hoogmartens, D. Vanderzande, H. Martens, and J. Gelan, "Short communication," Synth. Met., vol. 47, no. 3, pp. 367-371, 1992, doi: 10.1016/03796779(92)90376-T.

[19] H. Zhu, X. Yan, J. Xia, and Y. Li, "Preparation and rheological properties of oil-water-coal triplex synfuel using petroleum sulfonate as the dispersants," Fuel Process. Technol., vol. 88, no. 3, pp. 221-225, 2007, doi: 10.1016/j.fuproc.2004.11.020.

[20] H. L. Qi, K. Gai, D. P. Ma, and B. Zheng, "Study on the Preparation of Oil-Coal-Water Slurry," Appl. Mech. Mater., vol. 716-717, pp. 11-15, 2014, doi: 10.4028/www.scientific.net/amm.716-717.11.

[21] S. C. Shukla, S. Kukade, S. K. Mandal, and G. Kundu, "Coal-oil-water multiphase fuel: Rheological behavior and prediction of optimum particle size," Fuel, vol. 87, no. 15-16, pp. 3428-3432, 2008, doi: 10.1016/j.fuel.2008.05.027.

[22] S. Kumar Majumder, K. Chandna, D. Sankar De, and G. Kundu, "Studies on flow characteristics of coaloil-water slurry system,” Int. J. Miner. Process., vol. 79, no. 4, pp. 217-224, 2006, doi: 10.1016/j.minpro.2006.02.004.

[23] G. S. Nyashina, G. V. Kuznetsov, and P. A. Strizhak, "Energy efficiency and environmental aspects of the combustion of coal-water slurries with and without petrochemicals," J. Clean. Prod., vol. 172, no. x, pp. 1730-1738, 2018, doi: 10.1016/j.jclepro.2017.12.023.

[24] D. O. Glushkov, S. Y. Lyrshchikov, S. A. Shevyrev, and P. A. Strizhak, "Burning Properties of Slurry Based on Coal and Oil Processing Waste," Energy and Fuels, vol. 30, no. 4, pp. 3441-3450, 2016, doi: 10.1021/acs.energyfuels.5b02881.

[25] S. S. Ibrahim, B. E. El Anadoly, M. M. Farahat, A. Q. Selim, and A. H. El-Menshawy, "Separation of pyritic sulfur from egyptian coal using falcon concentrator," Part. Sci. Technol., vol. 32, no. 6, pp. 588-594, 2014, doi: 10.1080/02726351.2014.933458.

[26] D. C. Rawlins, G. J. Germane, P. O. Hedman, and L. D. Smoot, "Laboratory-scale combustion of coal-water mixtures," Combust. Flame, vol. 63, no. 1-2, pp. 59-72, 1986, doi: 10.1016/0010-2180(86)90111-2.

[27] X. Zhang, Z. Chen, M. Zhang, L. Zeng, and Z. Li, "Combustion stability, burnout and NOx emissions of the 300-MW down-fired boiler with bituminous coal: Load variation and low-load comparison with anthracite," Fuel, vol. 295, no. x, p. 120641, 2021, doi: 10.1016/j.fuel.2021.120641.

[28] A. Shirneshan and H. Jamalvand, "Numerical investigation of combustion of biomass, methane, and gasoil fuels and emissions from a furnace chamber," Energy Policy Res., vol. 3, no. 1, pp. 19-26, 2016, doi: 10.1080/23317000.2015.1135303.

[29] I. Obernberger, T. Brunner, and G. Bärnthaler, "Chemical properties of solid biofuels-significance and impact," Biomass and Bioenergy, vol. 30, no. 11, pp. 973-982, 2006, doi: 10.1016/j.biombioe.2006.06.011.

[30] M. R. Akhmetshin, G. S. Nyashina, and P. A. Strizhak, "Comparative analysis of factors affecting differences in the concentrations of gaseous anthropogenic emissions from coal and slurry fuel combustion," Fuel, vol. 270, no. February, p. 117581, 2020, doi: 10.1016/j.fuel.2020.117581.

[31] G. V. Kuznetsov, K. Y. Vershinina, T. R. Valiullin, and P. A. Strizhak, "Differences in ignition and combustion characteristics of waste-derived oil-water emulsions and coal-water slurries containing petrochemicals," Fuel Process. Technol., vol. 179, no. July, pp. 407-421, 2018, doi: 10.1016/j.fuproc.2018.07.033. 